\title{
Roça como marca registrada no Brasil: novos significados do rural brasileiro
}

\author{
Roça as a brand in Brazil: new meanings of Brazilian rural \\ Lidiane Nunes da Silveira \\ Instituto Federal de Minas Gerais, Brasil \\ lidiane.nunes@ifmg.edu.br \\ Ana Louise de Carvalho Fiúza \\ Universidade Federal de Viçosa, Brasil \\ louise.fiuza@gmail.com
}

\section{Resumo:}

Este artigo buscou identificar mudanças nos significados do termo roça no Brasil analisando 325 marcas registradas entre 1965 e 2014, utilizando-se análise de conteúdo de frequência, léxico-sintática e categórica (Bardin, 1977). Observou-se a ampliação de significados, inicialmente de produção agrícola e campo, para natureza, nostalgia e sofisticação e, mais recentemente, tradição e regionalismos. Essas mudanças de significados do termo roça refletem as transformações no campo brasileiro, majoritariamente agrícola nos anos 1960, multissetorial nos anos 2000. Sugere-se que roça pode funcionar como uma categoria para se refletir sobre o rural no Brasil.

Palavras-chave: Roça, Marca registrada, Consumo, Análise de conteúdo, Brasil.

\section{Abstract:}

This article searched to identify changes in the meanings of the term roça in Brazil by analyzing 325 brands between 1965 and 2014, using frequency, lexical-syntactic and categorical content analysis (Bardin, 1977). It was observed the extension of meanings, initially of agricultural production and countryside, to nature, nostalgia and sophistication and, more recently, tradition and regionalisms. These changes of meanings of the term roça reflect the transformations in the Brazilian rural, essentially agricultural in the 1960s, multifunctional in the years 2000. It is suggested that roça could be used to think about rural in Brazil as a category of thought.

KEYWORDS: Roça, Brand, Consumption, Content analysis, Brasil.

\section{INTRODUÇÃo}

Neste artigo propõe-se explorar como a categoria roça pode elucidar aspectos importantes no entendimento do rural no Brasil. Historicamente, analisando-se obras e dados empíricos, percebe-se que roça pode variar seu sentido conforme o contexto e os sujeitos envolvidos, revelando que o rural pode ganhar valor simbólico ou econômico, como pode ser, por outro lado, estigmatizado e marginalizado. Por isso, retoma-se neste artigo, o argumento já defendido em trabalhos anteriores (Silveira e Fiúza, 2014) de que roça é uma categoria de uso nativo, operando entre os grupos sociais e seus contextos, de forma relativa e relacional (Lima, 1999).

Para tanto, parte-se do pressuposto de que a categoria nativa roça, recorrente em muitas regióes brasileiras, majoritariamente associada ao trabalho na lavoura, à produção de alimentos, ao campo como espaço geográfico e ao rural como modo de vida, pode ser, no Brasil, uma via de interpretação importante para a compreensão do rural e suas transformações. Outros termos análogos já foram estudados para compreender questões importantes sobre categorias sociais pertencentes ao campo, como a categoria caboclo, estudada por Lima (1999), sertão, discutido por Melo (2011) e mesmo a terminologia caipira, discutida em estudos considerados clássicos, como os de Candido (2010) e Ribeiro (2006). 
Roça, no Brasil, é um termo utilizado principalmente no senso comum,para se referir, entre outros significados, à lavoura, ao campo e ao rural (Silveira e Fiúza, 2014). Entretanto, roça é uma palavra "polissêmica e escorregadia" (Santos, 2006, p. 92) pois, além destas expressões, reúne uma variedade semântica notável que, dentro do universo discursivo relacionado à cultura rural, pode cambiar seus usos e significados. Assim, no Brasil, também costumava-se utilizar a expressão roça para demarcar fronteiras sociais, especialmente para estigmatizar grupos formados por pequenos agricultores familiares pobres moradores do campo, impingindo-lhes estereótipos e posições sociais inferiores, especialmente em contraponto aos segmentos urbanos. A partir dos anos 1980, no entanto, tem se ampliado o uso do termo roça como marca de produtos e serviços, especialmente de bens alimentícios e bebidas e do setor gastronômico, turístico e cultural, revelando um processo em curso de mudança semântica valorativa da palavra roça. Embora esta expressão já figurasse na indústria cultural há alguns anos, em peças literárias e na música, por exemplo, sua adoção na esfera publicitária parece revelar uma nova função no uso da palavra roça, marcada agora pela atração, pela valoração e valorização e, porque não, pela distinção (Silveira e Fiúza, 2014). Nesse sentido, sugere-se que a categoria roça poderia contribuir para a compreensão dos aspectos concernentes ao rural no Brasil, permitindo uma leitura acerca de suas configurações sociais. O que se pretende com a discussão proposta neste artigo é apontar um campo de pesquisa que pode se revelar profícuo de sentidos e contribuir para a compreensão de diferentes processos sociais relacionados às transformações no campo no Brasil a partir do termo roça.

O termo roça tem aparecido nos estudos que compõem o pensamento social brasileiro e o campesinato conformando parte da bibliografia sobre a Sociologia Rural no Brasil. Mas a categoria roça não tem sido analisada em si mesma, buscando seus significados e contextos, nem tem havido uma reflexão acerca de sua recorrente associação com a lavoura, a produção de mantimentos, o campo e o rural em muitas regióes brasileiras e no decorrer da história do país. Além disso, roça é amplamente utilizada como sinônimo de campo e rural na música, na literatura, em programas de entretenimento na televisão, por exemplo, como se constatou em pesquisa anterior (Silveira e Fiúza, 2014). A proposta de se refletir sobre os significados de roça e sua possível associação com o rural justifica-se, ainda, pela ampliação, a partir de meados dos anos 1980, de produtos e serviços considerados "da roça", tornando o termo, inclusive, em alguns casos, marca registrada de alguns bens de consumo.

Por outro lado, alerta-se para os limites de se utilizar o termo roça para compreender aspectos do rural no Brasil, especialmente por se tratar de uma categoria nativa, possuindo limites regionais de uso, polissemia, além de se tratar de um brasileirismo (Oliveira, 2012), impossibilitando análises comparativas ou mesmo uma universalização do termo. A categoria roça faz parte, portanto, da complexidade do rural brasileiro e apesar dos limites destacados, pode fornecer alguns indícios sobre algumas de suas características mais marcantes e suas principais transformações.

Para tanto, optou-se por analisar, a partir de evidências encontradas em pesquisa anterior (Silveira, 2015), o mercado de bens e serviços que veiculam o termo roça como marca, acreditando-se que o uso dessa expressão no mercado parece ser um indicador das transformações em curso no campo no Brasil, especialmente a partir de meados dos anos 1980, e de uma possível revalorização do rural. Assim sendo, corrobora-se com Anjos e Caldas (2014, p. 52) quando afirmam que:

Como é possível falar de uma nova ruralidade sem evocar os traços que sustentam as representações sociais construídas pelos consumidores, supostamente ávidos por absorver a tradição e o singular, em detrimento do padronizado, do convencional?

Tem-se como objetivo, portanto, analisar os significados do termo roça nas marcas de produtos e serviços a fim de verificar se o uso da expressão roça, como marca, possibilitaria a compreensão de aspectos do rural no Brasil e o possível processo de revalorização deste. Para isso, utilizou-se três técnicas da análise de conteúdo (frequência, léxico-sintática e categórica), de acordo com os procedimentos de Bardin (1977) para analisar uma amostra de 385 marcas de produtos e serviços com o termo roça em processo de registro ou já 
registradas no Instituto Nacional de Propriedade Industrial (INPI), no Brasil, entre os anos de 1965 e 2014. O referencial teórico que embasou a construção dessa análise e a discussão dos resultados revela as mudanças no campo e no rural na sociedade moderna e na contemporânea, no Brasil e em outros países. Sumariamente, trata-se da transformação do campo majoritariamente agrícola, carente de serviços, isolado e marginalizado frente à cidade e à sociedade industrial, dando lugar ao campo como espaço de conservação da natureza e desenvolvimento sustentável, entre outras características. Por meio desses novos arranjos produtivos, o campo vem oferecendo novas oportunidades de trabalho e renda para sua população, por meio do turismo, por exemplo, e como modo de vida alternativo às populações oriundas urbanas, os neo-rurais, construindo também um novo imaginário sobre o rural e abrindo um leque de possibilidades de superação da desigualdade social e do impacto ambiental. Os detalhes sobre tais aportes teóricos e os procedimentos metodológicos serão apresentados na sequência.

\section{REFERENCIAL TEÓRICo}

O termo roça, no Brasil, pode ser considerado um brasileirismo (Oliveira, 2012, p. 758) pelas suas características objetivas e também pela sua aplicabilidade sociolinguística. Para Candido (2010), Holanda (1994, 1995) e Ribeiro (2006), roça aparece atrelada à cultura caipira desenvolvida no interior dos Estados de São Paulo, no sul de Minas Gerais e do Rio Janeiro, parte de Goiás, Mato Grosso e Paraná. Nesse contexto, roça aparece formada pelo pequeno agricultor autônomo e sua família nuclear e também relacionada ao movimento das Bandeiras, de conquista de novos espaços e do estabelecimento de plantaçóes ao longo desses caminhos, formando núcleos de provisão de alimentos às minas. Candido (2010) se refere aos caipiras do interior paulista como roceiros e utiliza o termo roça para se referir tanto às lavouras quanto ao local, como sinônimo de campo ou rural, quando fala das "pessoas da roça", do "homem da roça" ou da "gente da roça"(Candido, 2010). Este autor assume a existência de uma estratificação social na cultura rural paulista, falando especialmente do período pós-ciclo bandeirante, no século XVIII, dividindo, de um lado, os proprietários de fazendas de cana, gado e café, e, de outro lado, os sitiantes. No entanto, Candido (2010) considera que tanto os fazendeiros, quanto os sitiantes e posseiros têm uma origem em comum nos mesmos troncos familiares, tendo feito parte dos "sítios de roça" que, segundo ele, seriam territorialmente avantajados e sem uma nítida distinção entre a grande e a pequena propriedade.

A expressão sítios de roça também é recorrentemente empregada por Holanda (1994, 1995), especialmente nos seus estudos sobre o estado de São Paulo no período colonial. A referência aparece, muitas vezes, em contraste com a vila, a cidade ou as sedes urbanas em geral, perfazendo o sítio da roça o espaço no campo onde se produz os mantimentos, sendo a expressão empregada tanto como "espaço rural" quanto como "espaço de produção". Holanda $(1994,1995)$ também se refere ao agricultor e à população que vive no campo no período colonial como roceiros, expressão que vai se tornando escassa no vocabulário acadêmico sobre estudos rurais no Brasil.

Já na obra de Freyre (2003), as menções à roça são sempre feitas com a conotação de lavoura, às vezes chamando-a de roçado. Da mesma forma, Prado Júnior (2011) refere-se à roça especialmente em termos das práticas agrícolas, bem como faz referência à lavoura de subsistência que, segundo ele, teria dado origem a uma forma particular de exploração agrícola, destinada à produção de gêneros alimentares, diferenciada do que denomina de grande lavoura.

O estudo de Oliveira (2012), embora publicado recentemente, oferece um panorama dos diferentes usos e significados do termo roça na literatura sobre o Brasil Colônia. Oliveira (2012, p. 757) destaca que as roças eram unidades dedicadas "única e exclusivamente à produção", contrapondo-as às casas de campo destinadas ao lazer. Segundo este autor, as roças eram conduzidas por mão de obra familiar de trabalhadores agregados à monocultura e/ou escravos, e a sua principal função seria o abastecimento de núcleos urbanos vizinhos e rurais, função que ainda hoje cumpririam nas "regiões menos populosas do país" (Oliveira, 2012, p. 758). 
A roça como unidade de produção é assim descrita por alguns estudos do campesinato brasileiro, como os de Moura (1978), Garcia Júnior (1983) e Heredia (1979), cada unidade econômica corresponderia a uma família nuclear dividida entre unidade de produção (roça) e unidade de consumo (casa) reproduzindo a oposição entre atividades domésticas e atividades agrícolas. Caberia à mulher o trabalho da "casa" e ao homem o da "roça". Essa divisão do trabalho marcava também a reprodução social, pois, segundo Moura (1978), de acordo com as respectivas faixas etárias, as meninas dedicavam-se, aos poucos, às tarefas domésticas e os meninos assumiam as atividades na roça. A divisão das tarefas por gênero no campesinato, pode ser compreendida na seguinte passagem: "Não há dúvida de que o lugar que os diferentes membros ocupam dentro do grupo doméstico está estreitamente ligado à sua posição com relação às atividades que desenvolvem no 'roçado' ou na 'casa'."(Heredia, 1979, p. 77).

Nos estudos sobre o campesinato, no entanto, ainda se pode perceber como a roça era uma categoria também empregada para organizar os grupos rurais em termos hierárquicos, uma vez que aqueles que estabelecem roças seriam, em geral, pequenos produtores rurais familiares que produziam para autoconsumo. Para Queiroz (1973), por exemplo, o campesinato, considerado por ela como uma camada social intermediária, era formado pelos descendentes dos trabalhadores que se dedicavam às roças no Brasil Colônia, formados a partir de fatores como a decadência do engenho e da mineração. A autora contrapunha a "roça" a "cultura comercial" no interior de São Paulo, onde a primeira seria o foco central de dedicação do trabalho da família, garantindo sua provisão, enquanto, no segundo caso, o foco do trabalho familiar é a plantação destinada ao comércio e a roça seria apenas uma complementação desta. Além disso, segundo Queiroz (1973), haveria uma formação hierárquica da sociedade rural em torno da roça simbolicamente expressa nos rituais nas ocasióes festivas por ela estudadas. Nas danças, por exemplo, os fazendeiros e donos de armazém ocupavam as posiçóes privilegiadas, seguidos pelos donos de pequenas roças que se sobrepunham àqueles que não possuíam roça nenhuma. Queiroz (1973) também ressalta que à medida em que as melhores terras eram ocupadas pela grande monocultura as roças camponesas ficavam restritas às piores terras.

Os processos hierárquicos que permeiam o uso do termo roça ainda aparecem em obras recentes, como no estudo de Brandão (2009) que demonstra como, para os camponeses, a ideia de roça ainda revela uma relação vertical que se remete à questão agrária e à relação entre os proprietários, como revelam as expressões "roças do fazendeiro" e "roças de meia"; "roça grande" e "roça virgem". Para Santos (2006), o processo histórico de ocupação das terras da região pelos colonizadores conferiu à roça, ao longo do tempo, uma conotação depreciativa por se tratar de pequenas propriedades cuja posse se deu por formas marginais e assimétricas em relação ao grande proprietário.

Santos (2006) relata que, inicialmente, na história da formação agrária do Recôncavo, a roça era a área de terra destinada ao cultivo e a plantação dela resultante. Entretanto, segundo ele, o processo histórico de fragmentação das propriedades em domínios cada vez menores, fruto das heranças e sucessões, levaram à correspondência entre roça como área de cultivo e como pequena propriedade. Daí que, segundo o autor, para as populações rurais simples do Recôncavo roçatem o significado de propriedade, terreno e também tem o sentido de rural. Conforme indica este autor, percebe-se, portanto, um processo de metonímia em que roça, tida como área da lavoura, vai se tornando sinônimo de rural. Entretanto, não de um rural generalizado, mas específico, qual seja, da pequena propriedade, não tendo a mesma conotação para se referir à fazenda ou ao engenho, conforme ressaltou o autor. Para Santos (2006), inclusive, o caráter pejorativo que roça recebe nessa região estaria relacionado à sua submissão à fazenda e ao engenho e ao status de uso e não de posse da terra. Portanto, de acordo com este autor, na região do Recôncavo Sul da Bahia, e até mesmo em outras regióes do Nordeste, roça teria a equivalência de rural.

Nesse sentido, Oliveira (2012) também destaca o caráter pejorativo de alguns termos que são empregados em muitos contextos sociais com o intuito de inferiorizar o homem do campo, principalmente, num processo de hierarquização em que a gente da cidade estaria colocada em posição de superioridade. Alguns destes termos, citados pelo autor, são "caipira, capiau, matuto, tabaréu e vazanteiro", assim como "lavrador ou 
roceiro" vocábulos estes utilizados no Brasil para se referir àquele que trabalha na roça (Oliveira, 2012, p. 758-759).

Entretanto, conforme argumenta-se neste artigo, nos últimos anos parece estar havendo uma inflexão dos usos e significados do termo roça, no Brasil. Sobre tais mudanças, destaca-se o trabalho de Carvalho e Sabino (2013) que faz uso da categoria roça apresentando outra significação deste termo, utilizado por grupos oriundos da camada média urbana da cidade do Rio de Janeiro, considerados por eles naturalistas, ou seja, adeptos da "alimentação natural, vegan e alimentação vivo" (Carvalho e Sabino, 2013, p. 15). Na visão dos naturalistas desta cidade, a roça é por eles classificada numa oposição binária à cidade, numa perspectiva que os autores consideram neorromântica, idílica e ressacralizadora da natureza. Para estes consumidores de alimentos naturais, o modo de vida no campo, traduzido por eles como roça, é considerado puro, saudável, positivo e feliz, em contraposição à cidade, vista como suja, impura, negativa, insalubre. $\mathrm{O}$ alimento da roça, para estes grupos, traduziria uma visão de mundo e um estilo de consumo, práticas alimentares e comensalidade adotadas em suas vidas cotidianas e consideradas por eles como naturais. No entanto, os autores revelam uma postura crítica ao perceberem a sacralização da cultura popular e da roça pelas camadas médias urbanas como um processo de legitimação do discurso dominante de classe a respeito da política de saúde e nutricional. Haveria, para Carvalho e Sabino (2013), nesse sentido, uma romantização da pobreza do campo por parte da população urbana de classe média, que embora reverencie e siga algumas práticas alimentares da roça, não se desvincularia totalmente do seu modo de vida urbano. Apesar do cunho crítico, o trabalho de Carvalho e Sabino (2013) é aquele que mais se aproxima dos novos significados que o termo roça tem adquirido entre alguns grupos sociais contemporâneos, especialmente devotados à produção, circulação e consumo de produtos alimentares, bens culturais e serviços considerados da roça.

Os textos consultados elucidam como a categoria roça funciona como operador simbólico das relações sociais brasileiras, especialmente entre grupos rurais e urbanos, estruturando tais interações num plano hierárquico de estereótipos e estigmas sociais que parecem conter sua raiz no processo histórico da formação agrária brasileira. Mas também revelam algumas transformações em curso, bastante recentes, relacionadas às mudanças de hábitos alimentares e modos de vida das camadas médias urbanas, que têm buscado inspiração na cultura rural para satisfazer às suas aspirações para seguir um modelo de vida saudável e alternativo ao estilo urbano moderno ocidental. Diante do exposto, ressalta-se que a bibliografia consultada permite antever a possibilidade de se pensar o termo roça como uma categoria importante para se pensar as especificidades da ruralidade brasileira. A palavra roça, portanto, e seu caráter polissêmico, revelam aspectos sobre as configurações sociais, processos de hierarquização e flexibilização das diferenças, sobre processos agrários e agrícolas, no Brasil, muito além da complexidade já assinalada pelos sinônimos lavoura, campo e rural que permeiam os significados da categoria aqui examinada.

A associação entre o termo roça e o rural, no Brasil, aqui proposto, também se respalda no fato de que tais transformações constatadas sobre o uso da categoria roça parecem ocorrer de forma análoga com a própria perspectiva do rural brasileiro e também em outros países. De acordo com Oliveira (2003), podese destacar que no Brasil, desde a proclamação da República até meados da década de 1950, a imagem do rural caracterizou-se pela valorização do homem do campo, tido como modelo para a construção de uma identidade nacional, com uma visão romântica de sua suposta inocência, simplicidade e honestidade. Contudo, esse imaginário seria ambíguo ao apontar também o homem de origem rural como preguiçoso e desmotivado, marginalizado do projeto de nação em vias de se urbanizar e se industrializar. Em um segundo momento, dos anos 1950 até o final dos anos 1970, durante o processo de urbanização e industrialização mais intenso no Brasil, além da modernização agrícola acentuada, o rural, como um todo, foi identificado ao atraso, ao tradicional e conservador, em detrimento à cidade, moderna e desenvolvida, como destaca Oliveira (2003). A partir dos anos 1980, contudo, estudos analisados no Brasil, como os de Alem (1996), De Paula (1998, 2001), Éboli (2007), Oliveira (2003) e Silva (2009), entre outros, apontam para uma valorização do rural a partir da crítica ao modelo civilizatório urbano, ao culto da natureza mas também pela estética country 
ressignificada a partir das referências culturais norte-americanas. Este processo de valorização do rural foi apontado por Entrena-Durán (2012) na Espanha pós-produtivista, pós anos 1980, marcado especialmente pelo desenvolvimento do turismo rural e suas dinâmicas inerentes: neo-rurais, valorização da qualidade de vida no campo, crítica à agricultura produtivista e processos de conservação da natureza e dos aspectos de vida locais. As transformações do imaginário brasileiro ao longo do século XX encontram correspondência àquelas ocorridas na Espanha no mesmo período, conforme descreveu Entrena-Durán (2012). O autor destaca que, ao longo do século XX, na Espanha, houve três diferentes fases do imaginário coletivo sobre o meio rural: amitificação conservadora durante o regime franquista, entre 1940 e 1950; o desenvolvimentismo e a modernização dos anos 1960 e 1970 que despertou um sentimento de menosprezo ao rural identificado com o atraso sociocultural e o subdesenvolvimento econômico; a revalorização do rural, a partir dos anos 1980, a partir de uma reinvenção do rural e de sua mitificação com um recorte neo-ruralista. A volta ao rural, para o autor, não seria marcada por uma perspectiva de retorno à sociedade agrária tradicional, mas, antes, por uma perspectiva orientada pela qualidade de vida e pelo desenvolvimento sustentável. As transformações do imaginário coletivo sobre o rural em direção à sua revalorização estariam relacionadas à expansão do turismo rural e à moradia no campo, dentre outras manifestações da expansão das interligações entre citadinos e rurais, o que sugere certa flexibilização das fronteiras hierárquicas demarcatórias das relações entre o rural e o urbano.

Resta analisar, conforme propõe-se neste trabalho, como o uso do termo roça, como marca de produtos e serviços no Brasil, pode revelar tais permanências e transformações no imaginário sobre o rural brasileiro e nas atividades produtivas do campo desde meados do século XX até o início do novo milênio. Esta tentativa foi realizada ao se analisar os pedidos de registro de marcas de produtos e serviços, no Brasil, com o termo roça, a partir das técnicas de análise de conteúdo (Bardin, 1977) descritas a seguir.

\section{Metodologia}

Com o objetivo de analisar os usos e significados do termo roça como marca, no Brasil, consultou-se o banco de dados do Instituto Nacional de Propriedade Industrial (INPI), do Ministério da Indústria, Comércio e Desenvolvimento Exterior do Brasil, órgão responsável pelo registro de marcas e concessão de patentes nesse país. A partir da identificação de todos os processos que solicitavam o registro de produtos e serviços com a marca roça, realizou-se uma análise descritiva dos dados, levando em conta sua evolução temporal, frequência, tipos de produtos e serviços e uma análise de conteúdo categórica, descritiva de frequência e léxico sintática, com base na técnica orientada por Bardin (1977). Cada um desses procedimentos será descrito com mais detalhes a seguir.

\subsection{Análise descritiva dos dados}

A consulta ao banco de dados do INPI foi realizada entre 2013 e 2014. Foram identificados, ao todo, 325 processos que solicitavam registro com a marca roça no INPI, entre os anos de 1965 e 2014. Esses processos continham informações sobre a classificação dos bens como produto ou serviço realizada pelos seus titulares, com base nas edições 7 $7^{\mathrm{a}}, 8^{\mathrm{a}}$, 9 a e 10a da Classificação Nacional e da Classificação de Nice.

Efetuou-se, então, um reagrupamento das classificações de produtos e serviços, visando tornar essas informações mais sintéticas para a análise. Na categoria produtos, construiu-se o reagrupamento: alimentos, bebidas, utensílios domésticos, beneficiamento, bioquímicos, máquinas, vestuário, mobiliário, armarinho, minerais e fumo. A categoria serviços foi reorganizada nas seguintes subdivisões: negócios, cultura, gastronomia e turismo. Organizou-se os dados, também, segundo sua frequência temporal, dividindo-os em cinco décadas de registros de 1965 a 2014. 
Em seguida, realizou-se as análises descritivas das marcas roça. Para cada década foram descritas a quantidade de solicitações de registro de marcas com o termo roça; o número de produtos e serviços ou ambos; e quais eram os tipos de produtos e de serviços identificados. Os seus resultados serão apresentados e discutidos na próxima seção.

\subsection{Análise de conteúdo das marcas}

Com o banco de dados coletado no INPI, utilizou-se três procedimentos de análise de conteúdo, segundo as técnicas descritas por Bardin (1977): 1) análise descritiva de frequência das ocorrências das marcas; 2) análise lexical e sintática e 3) análise categórica ou temática. Efetuou-se, primeiramente, uma análise de frequência das ocorrências de cada marca, agrupando as repetidas e enumerando-as em ordem decrescente, visando não super-representar as análises léxico-sintática e categórica, bem como facilitando esse procedimento.

Posteriormente, seguiu-se os procedimentos descritos por Bardin (1977) para a realização da análise lexical sintática: tomou-se como base as convenções,primeiramente, observando-se o número total de palavras presentes (ocorrências) e o número total de palavras diferentes (vocábulos). Verificou-se, ainda, a relação entre as ocorrências e os vocábulos visando aferir o grau de riqueza/pobreza do vocabulário no repertório de marcas. Em segundo lugar, procedeu-se à distinção das unidades de vocabulário, identificando as palavras plenas e as palavras instrumentos, conforme define Bardin (1977). Essas duas etapas foram aplicadas separadamente a cada conjunto de décadas de produtos e serviços com a marca roça e os seus resultados foram analisados integralmente em função de não ter havido discrepâncias entre as décadas.

Para a análise categórica ou temática utilizou-se, como corpus, o conjunto de todas as marcas identificadas no INPI com o termo roça, considerando-se que ele atendia aos parâmetros recomendados por Bardin (1977), relativos à exaustividade e à representatividade da amostra, à homogeneidade dos dados, e à pertinência à proposta da análise. Após uma leitura flutuante, identificou-se as unidades de registro, que, em geral, foram formadas de uma a cinco palavras, numa média de três palavras. As marcas, aqui, podem ser pensadas como temas, por carregarem uma significação como uma unidade própria para a análise. Algumas marcas que são compostas por título e subtítulo foram observadas integralmente. As unidades de contexto consideradas foram a década, a classificação em produto ou serviço e suas subcategorias.

Os critérios que balizaram a criação das classes de diferenciação e, posteriormente, das categorias, seguiu o confronto dos dados empíricos, revelados pela própria amostra de marcas com o termo roça, a partir de uma leitura flutuante, com as questões teóricas que guiaram esta pesquisa e que permitiram a construção de inferências. Avaliou-se o conjunto das marcas com o termo roça, de 1965 a 2014, separando-as em quatorze classes, segundo suas características em comum, a saber: 1) lavoura/campo;2) produto agrícola/agropecuário; 3) agroindústria; 4) elementos materiais da cultura; 5) elementos simbólicos da cultura; 6) cultura urbana/ estrangeira; 7) distinção/sofisticação; 8) mercado; 9) sentidos/imaginário/memória; 10) tradição/artesanal/ autêntico/original; 11) natural/puro/verde; 12) orgânico; 13) mineiridade ou falar mineiro; e 14) caipira/ matuto/caboclo. Essas classes foram reagrupadas em oito categorias de classificação, que são as seguintes: 1) roça como sinônimo de campo; 2) roça como sinônimo de rural; 3) roça como tradição; 4) roça como apologia à natureza; 5) roça romântico-nostálgica; 6) roça estilizada; 7) roça em referência a Minas Gerais; e 8) roça com alusão ao caipira. Os resultados e respectivas reflexões que emergiram da análise de conteúdo das marcas com o termo roça, no Brasil, serão apresentados na seção adiante. 


\section{RESUltados E Discussão}

A análise descritiva dos dados colhidos no INPI revelou, inicialmente, a evolução dos pedidos de registro de marca, no Brasil, para o vocábulo roça, entre os anos de 1965 a 2014, que podem ser conferidos na Tabela 1 a seguir:

TABELA 1

Quantidade de solicitações de registro de marca com o termo roça no INPI, no Brasil, por décadas

\begin{tabular}{l|r|r}
\hline \multicolumn{1}{c|}{ DÉCADAS } & \multicolumn{2}{|c}{$\begin{array}{c}\text { SOLICITAÇÕES DE } \\
\text { REGISTRO } \%\end{array}$} \\
\hline $\mathbf{1 9 6 5 - 1 9 7 4}$ & 2 & 0,6 \\
\hline $\mathbf{1 9 7 5 - 1 9 8 4}$ & 5 & 1,5 \\
\hline $\mathbf{1 9 8 5 - 1 9 9 4}$ & 36 & 11,1 \\
\hline $\mathbf{1 9 9 5 - 2 0 0 4}$ & 111 & 34,2 \\
\hline $\mathbf{2 0 0 5 - 2 0 1 4}$ & 171 & $\mathbf{5 2 , 6}$ \\
\hline TOTAL & $\mathbf{3 2 5}$ & $\mathbf{1 0 0 , 0}$ \\
\hline
\end{tabular}

Fonte: Elaborado pelos autores a partir de dados coletados no site do INPI.

Nas duas primeiras décadas analisadas, entre 1965 e 1984, o número de solicitações de registro para a marca roça foi bastante reduzido. A partir de meados da década de 1980, no entanto, a quantidade de pedidos aumentou gradativamente. Destaca-se, sobretudo, que metade das solicitações feitas ao INPI para o registro com a marca roça se concentrou nos últimos dez anos, a partir de 2005, correspondendo a 52,6\% do total. $\mathrm{O}$ aumento da oferta e ou dos pedidos de registro de marcas com alusão à roça podem sugerir, entre outras possibilidades, a valoração dos produtos e serviços oriundos do campo e a valorização da cultura de origem rural.

Quanto ao tipo de bem consumido com a marca roça, a partir dos dados fornecidos pelo INPI, constatouse que se tratavam, em sua maioria, de alimentos (132), seguidos de bebidas (59), em especial a cachaça, o vinho e os sucos naturais. Em menor volume, apareceram os utensílios domésticos (7) e o beneficiamento de produtos alimentícios (5), além de outros (14), como o fumo, carvão vegetal, bioquímicos, maquinário, vestuário e mobiliário. Todos esses produtos tinham a sua produção associada à roça como lavoura, ou mesmo à agroindústria, em termos de uma prática produtiva típica do campo, sugerindo uma permanência em termos do uso dessa palavra. Os produtos relativos às utilidades domésticas, ao vestuário, ao mobiliário e ao armarinho fazem uma referência à cultura rural, aos modos de vida típicos do campo, ao empregar roça como sinônimo de rural em sua marca. A participação de cada tipo de produto no conjunto das marcas roça em processo de registro de INPI pode ser visto na Tabela 2 abaixo: 
TABELA 2

Evolução dos tipos de produtos e serviços com solicitações de registro com a marca roça no Brasil, no INPI

\begin{tabular}{|c|c|c|c|c|c|}
\hline Tipo & $\begin{array}{l}1965- \\
1974\end{array}$ & $\begin{array}{l}1975- \\
1984\end{array}$ & $\begin{array}{l}1985- \\
1994\end{array}$ & $\begin{array}{l}1995- \\
2004\end{array}$ & $\begin{array}{l}2005- \\
2014\end{array}$ \\
\hline \multicolumn{6}{|l|}{ Produtos } \\
\hline Alimentos & & 2 & 13 & $\overline{42}$ & 75 \\
\hline Bebidas & & 3 & 10 & 26 & 20 \\
\hline Utensilios domésticos & & 1 & 3 & 2 & 1 \\
\hline Beneficiamento & & & 2 & 3 & \\
\hline Bioquímicos & & & 1 & & 3 \\
\hline Máquinas & & & 1 & 1 & 1 \\
\hline Vestuário & & & & & 2 \\
\hline Mobiliário & & & 2 & & \\
\hline Armarinho & & & & 1 & \\
\hline Minerais & & & & & 1 \\
\hline Fumo & & & & & 1 \\
\hline Total de produtos & $\overline{0}$ & 6 & 32 & 75 & 104 \\
\hline \multicolumn{6}{|c|}{ Serviços } \\
\hline Negócios & 1 & & 5 & 18 & 37 \\
\hline Cultura & 1 & 1 & 4 & 17 & 15 \\
\hline Gastronomia & & & & 14 & 32 \\
\hline
\end{tabular}

Fonte: Elaborado pelos autores a partir de dados coletados no site do INPI.

Os dados expressos nessa Tabela 2 permitem afirmar que o principal ramo de atividade que faz uso do termo roça como marca é o referente aos alimentos e às bebidas. Os processos de registro desses produtos demonstraram uma tendência de aumento gradativo nas últimas três décadas (1985-2014), embora o setor de bebidas pareça ter se estabilizado nos dois últimos decênios. Os outros produtos apareceram de forma intermitente e em poucas quantidades, mas sugerem uma recorrência, também a partir de 1985.

Os primeiros registros da marca, embora em pouca quantidade, foram destinados tanto para produtos quanto para serviços, enquanto, nos anos 1970, já parecem indicar uma maior predominância dos produtos. A década de 1985-1994 foi marcada por uma predominância da oferta de produtos em relação aos serviços, especialmente de alimentos e bebidas, como já foi salientado. Na década seguinte, entre 1995-2004, ocorreu uma mudança e parte considerável das marcas com o termo roça teve seu registro requerido declarando seu setor de atividade concomitantemente como produto e serviço. Assim, o titular poderia proteger a marca para mais de um ramo de atividade e muitos deles fizeram a requisição de registro da marca roça não só para o produto, mas, também, para o seu próprio escritório de negócios. Essa ampliação da definição do ramo de atividade entre os anos de 1995 e 2004, também pode estar relacionada ao salto no número de solicitações de registro da marca roça. Embora as causas dessa mudança não estejam claras, o aumento de serviços (junto com os produtos) na década de 1995 foi uma tendência que se manteve entre 2005 e 2014, embora, nesse último decênio, os titulares tenham requisitado o registro da marca roça separadamente para produtos ou serviços, conforme é possível verificar na Figura 1 abaixo: 
FIGURA 1

Evolução dos produtos e serviços com solicitações de registro com a marca roça, no Brasil, no INPI

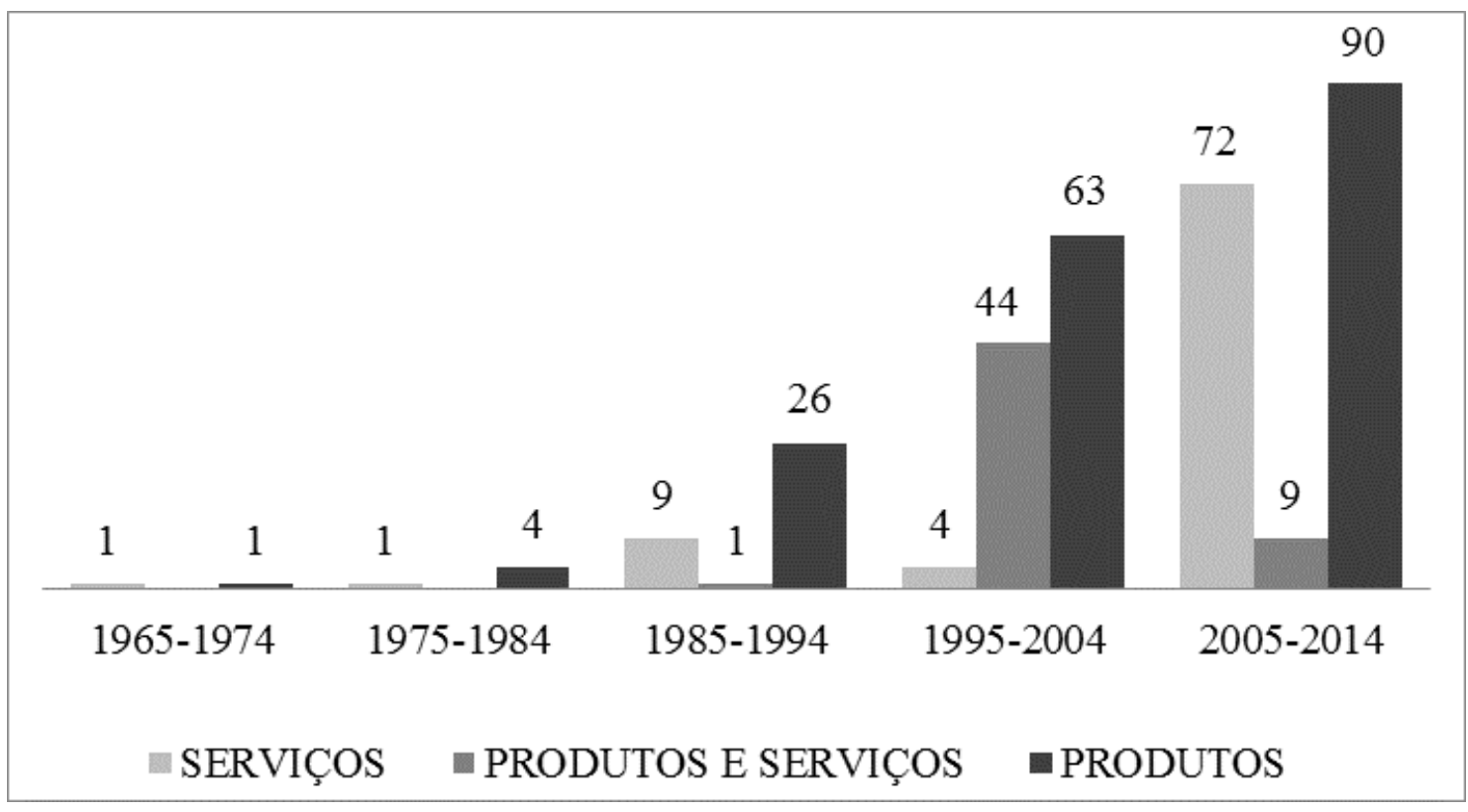

Fonte: Elaborado pelos autores a partir de dados coletados no site do INPI.

Constata-se, assim, que o aumento dos serviços que veiculam, como marca, o termo roça, no Brasil, desde meados da década de 1990, pode indicar, ao mesmo tempo, a difusão de uma cultura de um tipo de representação do rural na cidade, a qual se torna visível através da oferta não só de serviços relacionados à produção agrícola, mas, principalmente, de restaurantes, lanchonetes, festivais, programas televisivos de entretenimento e eventos culturais, no geral, que promovem algum tipo de experiência rural. Os tipos de serviços mais recorrentes que utilizam a marca roça, no Brasil, são os negócios (61), a gastronomia (46), a cultura (38) e o turismo (6). Nesse sentido, o que autores, como Alem (1996) e De Paula (1998, 2001), já traduziram por meio da estética country, percebe-se também sob o rótulo roça, a promoção de uma estilização do rural que, autêntica ou tradicional, apropriada pela indústria cultural ou não, reinventa e atualiza um rural que, de repente, não é mais sinônimo de atraso, de inferior, de marginalizado, mas se torna atraente. Por outro lado, o desenvolvimento do setor de serviços com a marca roça, nas duas últimas décadas, também pode ser expressão das mudanças no próprio campo, conforme apontado por Abramovay (1994), Silva (1997, 2001), e Veiga $(2004,2006)$. O estudo desses autores revelou que a multissetorialidade tem se tornado característica do campo no Brasil, ao superar a atividade agropecuária como ramo predominante e possibilitar a proliferação de novas ocupações e explorações relacionadas à conservação ambiental, ao lazer e fruição proporcionados pelo turismo rural e ecoturismo e pela própria cultura rural.

O crescimento de negócios e serviços de cultura com a marca roça foi gradativo, sobretudo, a partir da década de 1985, embora o último tenha se estabilizado. A gastronomia e o turismo só apareceram portando a marca roça a partir de 1995 e tiveram crescimento gradativo nesta última década (2005), embora os números do turismo sejam pequenos.

E, apesar dos negócios serem os serviços predominantes entre as marcas roça, os outros ramos de atividades declarados pelos titulares das marcas, a gastronomia, a cultura e o turismo, são reveladores dos usos e signficados que o mercado de bens e serviços fazem da categoria roça. Por meio deles se percebe a veiculação da cultura rural atrelada ao termo roça, que promove o consumo e a experiência, principalmente, da comida da roça, mas, também, de sua música, danças, religiosidade, festas típicas e do meio ambiente que, com maior evidência após os anos 1980, vem revestindo o rural de um novo significado, relacionado à natureza numa 
perspectiva romântica e idílica, conforme assinalam Anjos e Caldas (2014), Éboli (2007), Entrena-Durán (2012), Silva (2009), entre outros.

O crescimento do setor de serviços com a marca roça, nos últimos vinte anos, suscita várias hipóteses explicativas. Pode apontar para uma ressignificação do rural face ao processo de modernização do campo, acompanhando a trajetória citadina. Neste caso, o consumo do termo roça em marcas de serviços apontaria, inclusive, para uma extrapolação do uso inicial do vocábulo, vinculado à produção de gêneros alimentícios, associando-o agora a uma cultura com traços de autenticidade, com saber-fazer em consonância com a preservação ambiental e modos de vida considerados saudáveis, conforme sugere o estudo de Carvalho e Sabino (2013). Por fim, pode-se pensar, ainda, que o consumo da cultura rural pode significar uma crítica ao modelo de sociedade urbana e moderna e a reflexão sobre outros modos de vida possíveis, conforme argumentam Éboli (2007), sobre a audiência urbana do programa televisivo Globo Rural, e Silva (2009), sobre os assinantes citadinos da revista homônima.

Identificou-se, também, por meio da análise de conteúdo descritiva de frequência, uma recorrência das marcas mais utilizadas ao longo das décadas, conforme é possível observar na Tabela 3 abaixo:

TABELA 3

Frequência das marcas mais recorrentes com a palavra roça ao longo das décadas

\begin{tabular}{|c|c|c|c|c|c|}
\hline \multirow{2}{*}{ MARCA } & \multicolumn{5}{|c|}{ FREQUÉNCIA POR DÉCADA } \\
\hline & $1965-1974$ & 1975-1984 & 1985-1994 & $1995-2004$ & 2005-2014 \\
\hline Da Roça & & 2 & 6 & 11 & 12 \\
\hline Café da Roça & & & 3 & 9 & 10 \\
\hline Caminho da Roça & & & 2 & 5 & 4 \\
\hline Caninha da Roça & 1 & & 2 & 2 & \\
\hline Cantinho da Roça & & & & 4 & 3 \\
\hline Canto da Roça & & & & & 4 \\
\hline Casa da Roça & & & & & 3 \\
\hline Coisa da Roça ou Coisas da Roça & & & & 3 & 3 \\
\hline Delícias da Roça & & & 2 & 4 & \\
\hline Feijâo da Roça & & & & 5 & \\
\hline Produtos da Roça & & & & & 4 \\
\hline Sabor da Roça ou Sabores da Roça & & & 2 & 4 & 8 \\
\hline Tempero da Roça & & & & & 4 \\
\hline
\end{tabular}

Fonte: Elaborado pelos autores a partir de dados coletados no site do INPI.

Como pode ser notado, a marca mais frequente, ao longo das décadas, foi "Da Roça”, tendo aparecido nas quatro últimas décadas e com relativa frequência em cada uma delas. Essa marca mais utilizada ao longo dos anos é justamente a mais sucinta, que utiliza a categoria aqui estudada como a sua principal distinção no mercado de produtos e serviços. Destaca-se ainda que, como o volume de solicitações de registro com a marca roça foi crescendo a cada década, a variedade dos nomes também foi se diversificando, ao mesmo tempo em que as taxas de ocorrência de uma mesma marca se intensificaram. Por outro lado, entre as marcas mais populares com o nome roça, figuram aquelas que fazem alusão às características do bem material em questão, ressaltando o sabor, ou associando a mesma a espaços intimistas, como: casa, canto, cantinho ou caminho.

Ao se realizar a análise léxico-sintática das marcas pode-se constatar a riqueza e variedade do vocabulário, que se manteve relativamente estável ao longo do tempo. A variedade do vocabulário foi verificada utilizandose a técnica de Bardin (1977), de dividir o número de palavras total pelo número de palavras diferentes. A fórmula foi aplicada ao conjunto de marcas de cada década, obtendo-se taxas de que variaram de 1,5 a 2,87 
nos cinco decênios. Essa taxa do repertório do vocabulário é considerada de baixa repetição, ou seja, indica um vocabulário bastante variado para Bardin (1977).

Por outro lado, apesar da variedade do vocabulário identificada nestas marcas, observou-se um padrão, uma estrutura comum na maior parte delas: as marcas eram formadas por uma média de três palavras, constituídas por duas palavras plenas (com significado) ligadas por uma palavra instrumento (conectores), resultando na "fórmula": Substantivo + Adjetivo ou Substantivo + Locução adjetiva.

Segundo Guedes (2012), nomes de marcas costumam ser selecionados pelas empresas com o intuito de aludir às suas qualidades e atributos e são, para isso, formados por substantivos, adjetivos ou a combinação dos dois. Nesse sentido, parte das marcas aqui estudadas é formada pela seguinte estrutura: a palavra "roça" ocupando a função de substantivo e um adjetivo caracterizando-a, como no exemplo da marca "Roça Mineira"ou, ainda, pela marca "Roça Verde", podendo essa fórmula aparecer por meio da junção do substantivo com o adjetivo, criando-se uma única palavra, um neologismo, como, por exemplo: "Roçaboa"ou "Roçamax". Ou numa variação desse padrão, em que "roça" funciona como substantivo acrescentada de uma locução adjetiva, como nos exemplos "Roça de Minas”ou “Roça do Caipira”.

Mas o padrão mais recorrente, ao longo das décadas, para todas as marcas consideradas, foi aquele formado por: um substantivo qualquer (geralmente caracterizado pelo produto ou serviço oferecido) acrescido da locução adjetiva formada pela preposição "da" (na maioria das vezes, mas também aparece o "na") e a palavra "roça”, que é um substantivo, funcionando como um adjetivo, transformado pela morfologia, como nos exemplos: "Café da Roça”, "Sabor da Roça”, "Festa na Roça”, "Chick na Roça”, entre outros.

A identificação dessa estrutura morfológica, possibilitada pela análise léxico-sintática, permite sugerir algumas interpretações sobre o uso da palavra roça como marca de produtos e serviços. A primeira interpretação que se depreende é que, ao se utilizar o substantivo concreto "roça" numa locução adjetiva, ou seja, qualificando algum substantivo que veio antes dele, como "café", transformando-o num substantivo abstrato, está se supondo que "roça” reveste-se de alguma característica especial capaz de qualificar algum objeto, tornando-o distinto. Ora, os autores Guedes (2012), Massinelli (2014) e Silva (2014) afirmam que uma marca registrada tem como função principal tornar um bem ou um serviço distinto dos demais. Nesse caso, o operador da diferença e da distinção é o termo roça, aquele que dá significado ao objeto que se oferta ou se consome, mesmo quando já se trata de um substantivo abstrato, como "sabor". A segunda questão a ser sublinhada diz respeito à recorrente utilização da preposição "da" que funciona, nesse tipo de construção morfológica, para designar a procedência, a origem. Ou seja, a forma mais padronizada utilizada nas marcas com a palavra roça é aquela em que a descrição do produto ou serviço indica a sua origem, procedência, em termos de lugar: vem da roça, ou feito na roça, como nos exemplos citados acima.

Essas interpretações permitem pensar que há uma expectativa na oferta/demanda de produtos, especialmente dos alimentos, bebidas, beneficiados ou da agroindústria, de terem sido cultivados na lavoura, na roça, de onde foram colhidos e disponibilizados diretamente para o consumo, ou foram feitos de forma artesanal, caseira, familiar, na propriedade de uma família agricultora de pequeno porte. Ou seja, parece permanecer no imaginário a associação entre roça e produção de mantimentos, conforme descrita pelos autores sobre o significado desta na formação sócio histórica e no campesinato brasileiro. Entretanto, essa associação parece receber novas conotações, como se verá adiante, relacionadas à preocupação com uma alimentação natural, artesanal, livre de agrotóxicos e não industrializada, o que também sugere uma valorização da roça como atributo de tais produtos. Assim, há um conjunto de produtos (como vestuário, mobiliário, utensílios domésticos) e, mais especialmente, de serviços (gastronômicos ou culturais) que, ao atrelarem sua origem à roça, parecem sugerir a reprodução de um saber-fazer típico de um modo de vida rural, como nos exemplos: "Forró da Roça”, "Tradição da Roça”, "Arte da Roça” e "Cozinha da Roça”, entre outros.

Ambas as variações se resumem na marca mais frequente ao longo das décadas, "Da Roça”. A palavra roça figura nas marcas aqui estudadas para indicar a origem ou o modo de fazer relativo a um modo de vida típico. A categoria roça assinala, assim, um atributo genérico e não está relacionada com os processos 
formais de Indicação Geográfica (IG), como Indicação de Procedência (IP) e Denominação de Origem (DO), que certificam, através de selos, produtos ou serviços com características atreladas ao seu local de origem ${ }^{1}$. Mas a associação que pode ser feita entre o nome roça e a origem dos produtos e serviços parece sugerir uma série de significados a respeito da valorização do saber-fazer relacionado aos produtos agrícolas e também a um conjunto de comportamentos relativos ao modo de vida rural, como a gastronomia e a cultura, por exemplo. Para Santos (2014), a população urbana tem se interessado por produtos alimentícios que remetam ao rural, ao natural e cuja origem possa ser identificada, numa contrapartida aos processos de industrialização dos alimentos. Para a autora, alguns instrumentos, como a "Indicação Geográfica" e o "Registro de Bens Culturais de Natureza Imaterial" (patrimônio imaterial), têm sido utilizados para valorizar o que ela denomina de produtos alimentares tradicionais. Ainda que a roça não seja considerada em nenhum desses processos formais específicos, sua associação a alguns bens e serviços parece ser sintomática do mesmo fenômeno indicado por Santos (2014). O uso da palavra roça como marca de produtos e serviços parece oferecer uma ideia sobre a origem e inspirar a confiança na busca pela autenticidade entre os consumidores.

De acordo com Guedes (2012, p. 426), uma marca "deve ser rica em significados e valores, pois é através dela que a empresa promete e entrega ao cliente um valor superior ao que o mercado oferece". A autora ressalta ainda que a marca está ligada a "sentimentos, emoções e sensações" e deve ser sempre "atual" (Guedes, 2012, p. 421-422). Esses aspectos permitem pensar que o uso do nome roça na marca de produtos e serviços representa um conjunto de valores e significados, para o criador da marca, que denota imagens e sentimentos positivos para o consumidor, o que, de alguma forma, corrobora com a hipótese de que haveria uma ressignificação e uma valorização do rural, no Brasil que envolvem o imaginário sobre o rural e a sua evocação por meio da palavra roça. Nesse sentido, busca-se, a seguir, compreender mais detalhadamente os significados que envolvem o uso do termo roça como marca, utilizando-se, para isso, a análise de conteúdo categórica.

Os critérios que orientaram a categorização das marcas foram o léxico e o expressivo. O critério léxico buscou o sentido mais comum e o emparelhando dos sinônimos e significados próximos. Já o critério expressivo voltou-se para os diferentes recursos linguísticos com o objetivo de aguçar imagens, ideias e sentidos no consumidor. Assim, às vezes, modifica-se, nas marcas, a grafia da palavra, usa-se palavras originárias de outros idiomas, gírias, expressões coloquiais, cacoetes e etc. As categorias de significados das marcas com o termo roça analisadas são apresentadas no Quadro 1, a seguir:

\section{QUADRO 1}

Categorias da análise de conteúdo categórica

\begin{tabular}{l|l|l|l|l|l|l|l}
\hline $\begin{array}{c}\text { Roça } \\
\text { sinônimo } \\
\text { de campo }\end{array}$ & $\begin{array}{c}\text { Roça } \\
\text { sinônimo } \\
\text { de rural }\end{array}$ & $\begin{array}{c}\text { Roça } \\
\text { como } \\
\text { tradição }\end{array}$ & $\begin{array}{c}\text { Roça } \\
\text { como } \\
\text { apologia } \\
\text { à } \\
\text { natureza }\end{array}$ & $\begin{array}{c}\text { Roça } \\
\text { romântico- } \\
\text { nostálgica }\end{array}$ & $\begin{array}{c}\text { Roça } \\
\text { estilizada }\end{array}$ & $\begin{array}{c}\text { Roça em } \\
\text { referência } \\
\text { a Minas } \\
\text { Gerais }\end{array}$ & $\begin{array}{c}\text { Roça } \\
\text { com } \\
\text { alusão } \\
\text { ao } \\
\text { caipira }\end{array}$ \\
\hline $\begin{array}{l}\text { Lavoura/ } \\
\text { Campo }\end{array}$ & $\begin{array}{l}\text { Elementos } \\
\text { materiais } \\
\text { da cultura }\end{array}$ & $\begin{array}{l}\text { Artesanal/ } \\
\text { autêntico/ } \\
\text { original/ } \\
\text { tradição }\end{array}$ & $\begin{array}{l}\text { Natural/ } \\
\text { puro/ } \\
\text { verde }\end{array}$ & $\begin{array}{l}\text { Sentidos/ } \\
\text { imaginário/ } \\
\text { memória }\end{array}$ & $\begin{array}{l}\text { Distinção/ } \\
\text { sofisticação }\end{array}$ & $\begin{array}{l}\text { Mineiridade } \\
\text { ou } \\
\text { expressões } \\
\text { dos falares } \\
\text { mineiros }\end{array}$ & Caipira \\
\hline $\begin{array}{l}\text { Produto } \\
\text { agrícola/ } \\
\text { agropecuário }\end{array}$ & $\begin{array}{l}\text { Elementos } \\
\text { simbólicos } \\
\text { da cultura }\end{array}$ & & Orgânico & & $\begin{array}{l}\text { Cultura } \\
\text { urbana/ } \\
\text { estrangeira }\end{array}$ & Matuto \\
\hline Agroindústria & & & & & Mercado & & Caboclo \\
\hline
\end{tabular}


Na definição das classes que formaram a primeira categoria, "Roça como sinônimo de campo", considerouse as referências relativas ao produto em si, ou ao lugar de produção do gênero alimentício. Dentro desta categoria foram incluídas três classes. A primeira foi a classe referente ao lugar de origem do produto, como "Lá na Roça"; 2) a classe referente aos produtos agrícolas em si, como "Mandioca da Roça"; 3) a classe referente aos produtos da agroindústria processados tradicionalmente no campo, como "Queijo da Roça", "Farinha da Roça" ou "Cachaça da Roça". Já na segunda categoria, "Roça como sinônimo de rural" considerou-se as práticas relativas ao modo de vida rural. Assim agrupou-se, nessa classe, as marcas que revelavam elementos materiais da cultura rural, como "Panela da Roça", e elementos simbólicos da cultura rural, especialmente aqueles ligados à cultura e à gastronomia, como "Festa na Roça" e "Pão de queijo da Roça". A terceira categoria foi denominada "Roça romântico-nostálgica". Nela, considerou-se as indicações dos trabalhos de Anjos e Caldas (2014) e Entrena-Durán (2012), para se reunir as marcas que se relacionassem aos sentidos, como o paladar e o olfato, e aos processos cognitivos de imaginação e de memória, conforme indicou Silva (2009). Assim, foram catalogadas, nessa categoria, marcas como "Sabor da Roça", "Cheiro da Roça", "Recanto da Roça”. A quarta categoria foi denominada de "Roça Estilizada". Nela, buscouse abarcar as referências sobre o country e a estilização da cultura rural no Brasil (Alem, 1996; De Paula, 1998, 2001). Incluiu-se, assim, nessa categoria, as marcas que apontavam para o hibridismo entre a cultura rural e a urbana, através da utilização de palavras de línguas estrangeiras, ou das referências às formas de mercado tipicamente urbanas e palavras que sugerissem a sofisticação e a distinção. Assim, foram elencadas, nesta categoria, marcas como "Cachorro Quente da Roça”, "Shopping da Roça”, "La Fruit da Roça”, "Varejão da Roça" e "Roça Chic".

As demais categorias foram definidas por meio da identificação de palavras explícitas nas marcas que se referissem ao tema escolhido ou que lhe fossem correlatos. Assim, a quinta categoria foi denominada de "Roça como Tradição", considerando-se as classes que tivessem as palavras "tradição", "autêntico", "original", “artesanal”, com base nas discussões de Mannheim (1986) e Taylor (2011). Nela, foram categorizadas marcas como "Tradição da Roça”, "Original Palhas da Roça” ou "Produtos Artesanais Grão/Café da Roça”. A sexta categoria foi denominada "Roça como apologia à natureza", sendo formada pelas classes que continham as palavras "natural", "verde", "puro" ou "orgânico", como nas marcas "Roça Verde", "Roça Natural: produtos orgânicos". Essa categoria foi criada a partir das discussões de autores como Abramovay (1994), Anjos e Caldas (2014) e Éboli (2007). Na sétima categoria adotou-se a referência de "Roça relacionada a Minas Gerais", como base nas revelações dos dados empíricos, tendo sido consideradas, na definição da mesma, as discussões de Abdala (2007) Assim, elencou-se as classes que fizessem referência ao Estado brasileiro e à cultura de Minas Gerais ou ao atributo de ser mineiro, especialmente da comida mineira, ou expressóes que fossem identificadas com o falar mineiro, conforme explicam Gonçalves e Silva (2009), Rocha e Ramos (2010). Assim, foram identificadas marcas como "Roça Mineira" ou "Cachaça da Roça Uai”. Por fim, a oitava categoria tomou por base as discussões sobre a cultura caipira relatada por Candido (2010). Considerouse também a categoria "Roça Caipira" que englobou classes que contivessem, além da palavra "caipira", outras palavras relativas a tipos socioculturais brasileiros, como "caboclo" e "matuto". Os exemplos de marcas classificadas nessa categoria são "Caipira da Roça”, "Roça do Caboclo" e "Matuto Café da Roça”. A classificação das marcas nessas categorias resultou nos seguintes dados expressos na Tabela 4: 
TABELA 4

Categorias das marcas com o nome roça

\begin{tabular}{|c|c|c|c|c|c|c|c|c|}
\hline & $\begin{array}{l}\text { ROÇA } \\
\text { COMO } \\
\text { CAMPO }\end{array}$ & $\begin{array}{l}\text { ROÇA } \\
\text { COMO } \\
\text { RURAL }\end{array}$ & $\begin{array}{c}\text { ROÇA } \\
\text { COMO } \\
\text { TRADIÇÃO }\end{array}$ & $\begin{array}{c}\text { ROÇA } \\
\text { COMO } \\
\text { NATUREZA }\end{array}$ & $\begin{array}{c}\text { ROÇA } \\
\text { ROMÂNTICO- } \\
\text { NOSTÁLGICA }\end{array}$ & $\begin{array}{c}\text { ROÇA } \\
\text { ESTILIZADA }\end{array}$ & $\begin{array}{c}\text { ROCA } \\
\text { REFERẼNCIA } \\
\text { A MINAS } \\
\text { GERAIS }\end{array}$ & $\begin{array}{l}\text { ROÇA } \\
\text { CAIPIRA }\end{array}$ \\
\hline DÉCADAS & \multicolumn{8}{|c|}{ QUANTIDADE DE MARCAS EM CADA CATEGORIA } \\
\hline 1965-1974 & 2 & - & - & - & - & - & - & - \\
\hline 1975-1984 & 3 & 1 & - & - & - & - & - & - \\
\hline 1985-1994 & 55 & 3 & - & 1 & 3 & 3 & & \\
\hline 1995-2004 & 27 & 11 & 3 & 3 & 8 & 17 & 3 & 1 \\
\hline 2005-2014 & 35 & 14 & 3 & 2 & 18 & 32 & 7 & 6 \\
\hline
\end{tabular}

Fonte: Elaborado pelos autores a partir de dados coletados no site do INPI.

Como fica nítido na Tabela 4 acima, nas duas primeiras décadas, com os pedidos de registros de marcas com o nome roça bastante reduzidos, as temáticas giraram em torno das ideias de roça como sinônimo de campo e de rural. A diversidade temática surge com o aumento do volume de solicitações de registro para a marca roça, em meados dos anos 1980. No decênio compreendido entre 1985-1994, além das marcas que puderam ser classificadas nas categorias de roça como sinônimo de campo e rural, surgiram novos nomes que foram, nesta análise, identificados nas categorias "natureza", "romântico-nostálgica" e "estilizada". Sublinhase que foi exatamente nos anos 1980 e no início dos 1990 que emergiram os fenômenos de revalorização do rural a partir da preocupação com a sustentabilidade ambiental e de reestilização do rural a partir da indústria cultural, marcadamente a sociabilidade country, os programas de entretenimento de temática rural, o auge do sucesso da música sertaneja e a expansão das festas de rodeios (Abramovay, 1994; Alem, 1996; De Paula, 1998, 2001; Éboli, 2007; Oliveira, 2003; Silva, 2009; Veiga, 2004, 2006). Nas duas últimas décadas, de 1995 a 2014, as marcas mantiveram o padrão temático que permitiu que muitas delas pudessem, nesta análise, ser agrupadas nas mesmas categorias que já tinham figurado nos decênios anteriores. Devido ao volume de solicitações desse período, a diversidade também se ampliou. Ao contrário da década anterior, na qual as inovações ficaram por conta da natureza e do romantismo, por um lado, e do moderno estilizado e sofisticado, por outro, nos últimos períodos analisados, as novas ideias orbitam em torno de perspectivas mais tradicionais do que seria a roça. Essa perspectiva é expressa na própria categoria tradição, mas também na alusão ao Estado de Minas Gerais, à sua faceta rural do passado (Abdala, 2007) e à figura dos tipos socioculturais característicos da formação do povo brasileiro, especialmente o caipira, mas também o caboclo.

Porém, analisando-se a quantidade de marcas presentes em cada categoria, ao longo das décadas, tem-se algumas impressões diferentes sobre os usos e significados do termo roça no mercado de bens e serviços, conforme demonstra a Figura 2: 


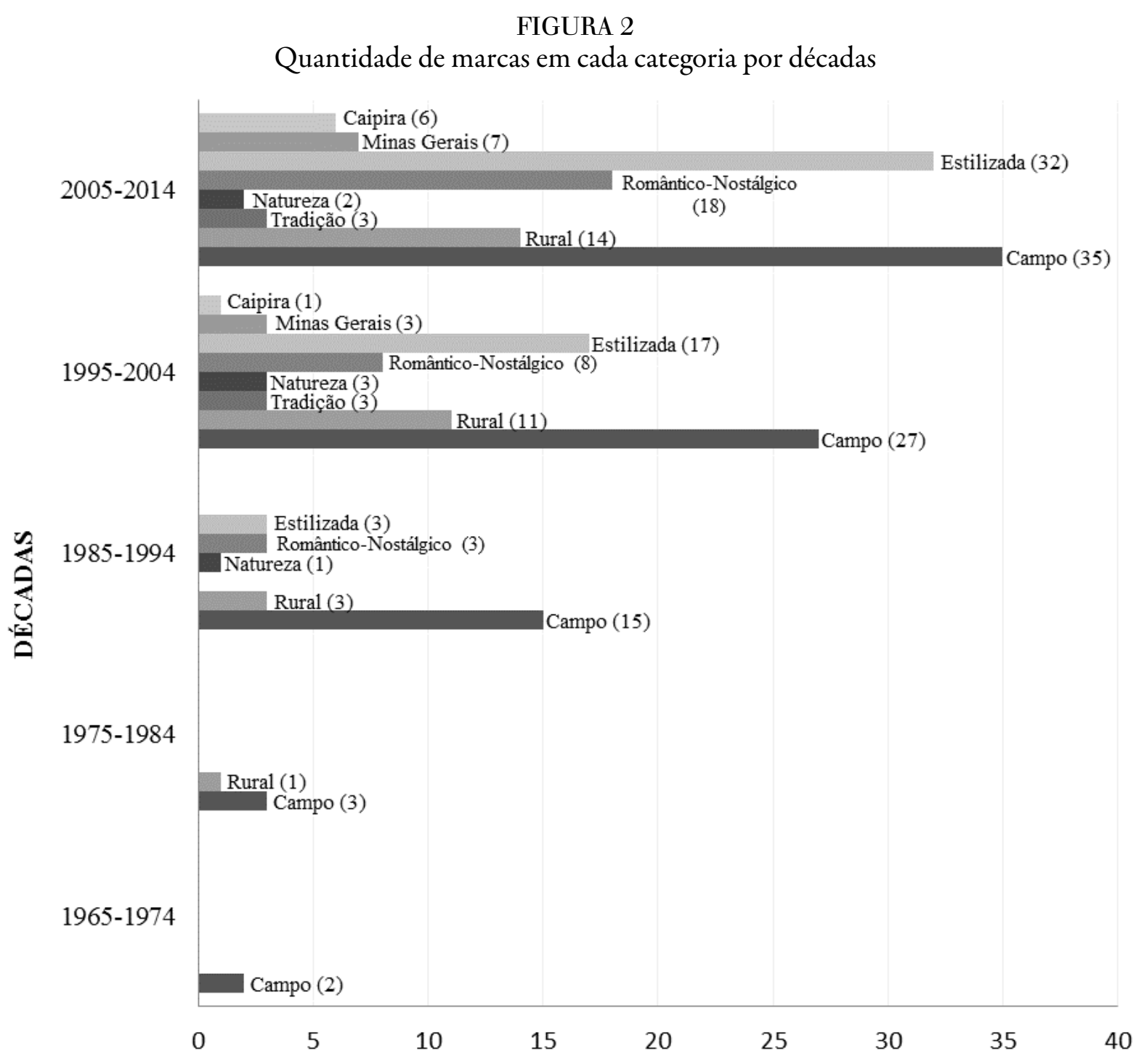

Fonte: Elaborado pelos autores a partir de dados coletados no site do INPI.

A Figura 2 revela que, além das categorias campo e rural estarem presentes nas cinco décadas, seu crescimento tem sido, relativamente, gradativo e constante. Enquanto as categorias natureza e tradição têm se mantido no mesmo estado, reduzido, as categorias romântico-nostálgica e estilizada cresceram substantivamente, sobretudo a última, tendo ultrapassado todas as outras nesse último decênio, com exceção da categoria campo. E as categorias caipira e Minas Gerais, mais recentes, também demonstram uma tendência de crescimento, embora seus números ainda sejam pequenos.

\section{Conchusões}

A diversidade de significados que compõe o uso do termo roça como marca de produtos e serviços na contemporaneidade parece sugerir um quadro amplo de compartilhamento de significados socialmente construídos do que seria roça. Essa miríade de definições compreende, por um lado, a reprodução de usos e significados historicamente engendrados do termo roça, como no sinônimo de campo e rural, especialmente no que se refere à marca de produtos alimentícios e bebidas. Por outro lado, nota-se a emergência de novos 
significados para este termo, subvertendo, portanto, as visões cristalizadas do que seria o rural em nome de um (novo) rural natureza, idílico, nostálgico e romântico. Esta visão, entretanto, convive com uma apropriação urbana, industrial e sofisticada que reinventa e estiliza o significado de roça. E, em contraposição a esse último, emergem significados de roça que buscam prestigiar elementos ligados à tradição, ao rústico, ao local e ao regional, expressos na ideia do caipira, da tradição e da mineiridade.

Esses diferentes usos e significados do termo roça como marca parecem coincidir com determinados momentos históricos característicos do rural no Brasil. O período compreendido entre as décadas de 1960 e 1980, no qual o campo era atrelado principalmente à produção agrícola (Abramovay, 1994; Silva, 1997, 2001), figura nas poucas solicitaçóes de registro de marca com a palavra roça, a maioria de produtos, entre estes alimentícios, e significações relacionadas ao campo e ao rural. A terceira década analisada, entre meados de 1980 e meados de 1990, parece ser um período de transição, em que aumentam os números de pedidos de registro para a marca roça, tanto para produtos quanto para serviços, em vários setores de atividades e surgem, de forma tímida, mas notável, novos significados para o termo entre as marcas, aludindo para questóes da natureza, da nostalgia, mas também do rural estilizado e mesclado com o urbano. E, nas duas últimas décadas, o mercado de bens e serviços com a marca roça parece, de alguma maneira, refletir o estado da arte do rural hoje, no Brasil. Aumentaram, consideravelmente, as requisições de registro com essa marca; os serviços, especialmente os negócios, a gastronomia e a cultura tornaram-se expressivos, revelando a multissetorialidade do campo, mas também a presença de uma cultura rural na cidade, além dos novos significados expressos em novos nomes apontarem para uma revalorização das origens, das raízes, além de traduzirem certa diversidade que contempla o campo e a cidade. Uma síntese dessa proposição é demonstrada na seguinte Figura 3:

\section{FIGURA 3}

Evolução das características históricas do campo, no Brasil e dos usos e significados da marca roça (1960-2015)

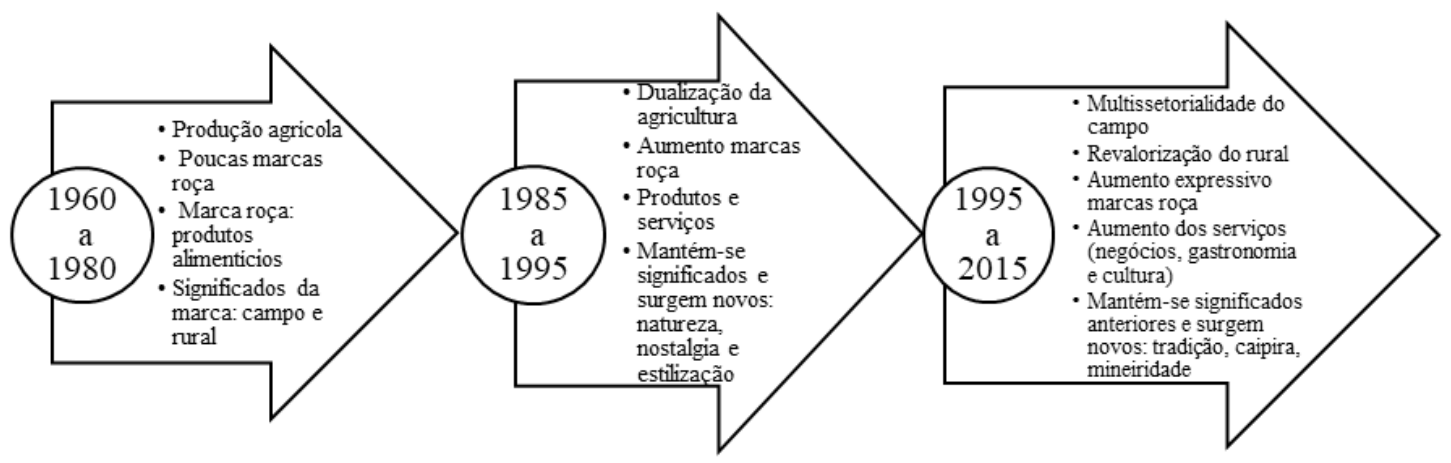

Fonte: Elaborado pelos autores

Os achados desta pesquisa sugerem, portanto, a partir da observação do uso de marcas registradas no mercado de bens e serviços, que o termo roça é expressivo das mudanças que ocorreram no campo no Brasil e na representação sobre o rural (também ocorridas em países de capitalismo avançado) desde a metade do século XX até o primeiro decênio do XXI. Por um lado, a pesquisa revela uma inflexão no próprio uso e significado do termo roça no Brasil, antes utilizado para se referir à produção agrícola de base familiar no campo, mas também para inferiorizar e estigmatizar, agora como sinônimo de natureza, nostalgia, tradição ou mesmo sofisticação. Por outro lado, a análise de conteúdo do uso do termo roça como marca de produtos e serviços no mercado brasileiro também sugere que a categoria nativa roça pode contribuir para o debate nada consensual a respeito da caracterização do rural. 


\section{REFERÊNCIAS BIBLIOGRÁFICAS}

Abdala, M. C. (2007). Re-atualizaçôes do tradicional e do típico mineiro. Artigo apresentado na VII Reunião de Antropologia do Mercosul, Porto Alegre, Brasil. CD-ROM.

Abramovay, R. (1994). A dualização como caminho para a agricultura sustentável. Estudos Econômicos, 24, 157-182.

Alem, J. M. (1996). Caipira e country: a nova ruralidade brasileira. (Tese de Doutorado inédita), Universidade de São Paulo, São Paulo, Brasil.

Anjos, F. S., e Caldas, N. V. (2014). Da medida do rural ao rural sob medida: um estudo sobre representações sociais em perspectiva. In Martins, R. C. (Ed.). Ruralidades, trabalho e meio ambiente: diálogos sobre sociabilidades rurais contemporâneas (pp. 49-76). São Carlos: EDUFSCAR.

Bardin, L. (1977). Análise de conteúdo. Lisboa: Edições 70/ LDA.

Brandão, C. R. (2009). No Rancho Fundo: Espaços e Tempos no Mundo Rural. Uberlândia: EDUFU.

Candido, A. (2010). Os parceiros do Rio Bonito: estudo sobre o caipira paulista e a transformação dos seus meios de vida. Rio de Janeiro: Ouro sobre Azul.

Carvalho, M. C. V., e Sabino, C. (2013). Comida natural: o consumo neorromântico da roça visto da cidade grande. In Ferreira, F. R., Freitas, R. F., Prado, S. D., e Carvalho, M. C. V. S. (Ed.). Alimentação, consumo e cultura (pp. 15-29). Curitiba: CRV.

De Paula, S. G. (1998). O country no Brasil contemporâneo. História, Ciências, Saúde - Manguinhos, V, 273-286.

De Paula, S. G. (2001). Quando o campo se torna uma experiência urbana: o caso do estilo de vida country no Brasil. Estudos: Sociedade e Agricultura, 17, 33-53.

Éboli, R. L. (2007). Globo Rural: mito e realidade do homem do campo. (Dissertação de Mestrado em Ciências Sociais em Desenvolvimento, Agricultura e Sociedade). Universidade Federal Rural do Rio de Janeiro, Rio de Janeiro, Brasil. Recuperado de: https://tede.ufrrj.br/jspui/handle/tede/624

Entrena-Durán, F. (2012). La ruralidade en España: de la mitificación conservadora al neorruralismo. Cuadernos de Desarollo Rural, 9 (69), 39-65.

Freyre, G. (2003). Casa-grande \& Senzala: Formação da Familia Brasileira sobre o Regime da Economia Patriarcal. São Paulo: Editora Global.

Garcia Júnior, A. R. (1983). Terra de trabalho. Rio de Janeiro: Paz e Terra.

Gonçalves, D. C. S., e Silva, T. F. (2009). As três zonas dialetais em Minas Gerais: discussão dos critérios utilizados para esta divisão. Trabalho apresentado no II Encontro Memorial: Nossas Letras na História da Educação. Mariana, Brasil. Recuperado de: http://www.ichs.ufop.br/memorial/trab2/l424.pdf

Guedes, S. A. (2012). Naming: a criação de nomes para as marcas. Renefara: Revista Eletrônica de Educação da Faculdade Araguaia, 2 (2), 412-428. Recuperado de: http://www.fara.edu.br/sipe/index.php/renefara/article/ view/77

Heredia, B. M. A. (1979). A morada da vida:trabalho familiar de pequenos produtores do Nordeste do Brasil. Rio de Janeiro: Paz e Terra.

Holanda, S. B. (1994). Caminhos e Fronteiras. São Paulo: Companhia das Letras.

Lima, D. M. (1999). A Construção Histórica do Termo Caboclo: Sobre Estruturas Representações Sociais no Meio Rural Amazônico. Novos Cadernos NEAE, 2 (2), 5-32.

Mannheim, K. (1986). O pensamento conservador. In Martins, J. S. Introdução Crítica à Sociologia Rural (pp. 77-131). São Paulo: Editora HUCITEC.

Massinelli, A. G. S. (2014). Marcas: uma análise histórica e conceitual do instituto. Jusnavegandi. Recuperado de: htt p://jus.com.br/artigos/32122/marcas-uma-analise-historica-e-conceitual-do-instituto

MELO, A. F. (2011). Sertões do mundo, uma epistemologia [manuscrito]; Uma cosmologia do sertão. (Tese de Doutorado em Geografia), Universidade Federal de Minas Gerais, Belo Horizonte, Brasil. Recuperado de: http://hdl.hand le.net/1843/MPBB-8PJKS3

Moura, M. M. (1978). Os herdeiros da terra: parentesco e herança numa área rural. São Paulo: Editora Hucitec. 
Oliveira, L. L. (2003). Do caipira picando fumo a Chitãozinho e Xororó, ou da roça ao rodeio. Revista USP, 59, 232-257.

Oliveira, M. A. (2012). As roças brasileiras, do período colonial à atualidade: caracterização histórica e formal de uma categoria tipológica. Varia História, 28 (48), 755-780. Recuperado de: http://www.scielo.br/scielo.php?pid=S 0104-87752012000200013\&script $=$ sci_abstract\&tlng=es

Prado Júnior, C. (2011). Formação do Brasil Contemporâneo: Colônia. São Paulo: Companhia das Letras.

Queiroz, M. I. P. (1973). O campesinato brasileiro: ensaios sobre civilização e grupos rústicos no Brasil. Petrópolis: Vozes. Ribeiro, D. (2006). O Povo Brasileiro: A Formação e o Sentido do Brasil. São Paulo: Companhia das Letras.

Rocha, A. P., e Ramos, J. M. (2010). Estudos de dialetologia em Minas Gerais: breve histórico. Revista de Estudos Lingüisticos e Literários, 41, 71-86.

Santos, F. J. S. (2006). Nem "tabaréu/oa", nem "doutor/a": o/a aluno/a da roça na escola da cidade: um estudo sobre identidade e escola. (Dissertação de Mestrado em Educação). Universidade do Estado da Bahia, Salvador, Brasil. Recuperado de: http://www.cdi.uneb.br/site/wp-content/uploads/2016/01/fabio_josue_souza_dos\%20santo s.pdf

Santos, J. S. (2014). Dilemas e desafios na valorização de produtos alimentares no Brasil: um estudo a partir do Queijo do Serro, em Minas Gerais, e do Queijo Serrano, no Rio Grande do Sul. (Tese de Doutorado em Sistemas de Produção Agrícola Familiar). Universidade Federal de Pelotas, Pelotas, Brasil. Recuperado de: https://www.sertaobras.org.br/wp-content/uploads/2015/01/Tese-Dilemas-e-desafios-na-valorizau00E7u 00E3o-de-produt-os-alimentares-tradicionais-no-Brasil.pdf

Silva, E. H. B. (2014). Registro de marcas no Brasil: registro de marcas ainda é pouco difundido no Brasil.Jusnavegandi. Recuperado de: http://jus.com.br/artigos/30485/registro-de-marcas-no-brasil

Silva, G. (2009). O sonho da casa no campo: jornalismo e imaginário de leitores urbanos. Florianópolis: Insular.

Silva, J. G. (1997). O novo rural brasileiro. Nova Economia, 7 (1), 43-81.

Silva, J. G. (2001). Velhos e novos mitos do rural brasileiro. Estudos Avançados, 15 (43), 37-50.

Silveira, L. N., e Fiúza, A. L. C. (2014). Roça e os múltiplos sentidos para o rural no Brasil. Revista Antropolitica, 37, 261-285. Recuperado de: http://www.revistas.uff.br/index.php/antropolitica/article/view/262/184

Silveira, L. N. (2015). Roça, uma marca registrada: o processo de valorização do rural na sociedade brasileira. (Tese de Doutorado em Extensão Rural). Universidade Federal de Viçosa, Viçosa, Brasil. Recuperado de: http://www.l ocus.ufv.br/handle/123456789/7503

Taylor, C. (2011). A ética da autenticidade. São Paulo: É Realizações.

Veiga, J. E. (2004). Destinos da ruralidade no processo de globalização. Estudos Avançados, 18 (51), 51-67.

Veiga, J. E. (2006). Nascimento de outra ruralidade. Estudos Avançados, 20 (57), 333-353.

\section{Notas}

1 Segundo informações do Ministério da Agricultura, Pecuária e Abastecimento (2015), disponibilizadas no seu site com o título Indicação Geográfica, "o registro de Indicação Geográfica (IG) é conferido a produtos ou serviços que são característicos do seu local de origem, o que lhes atribui reputação, valor intrínseco e identidade própria, além de os distinguir em relação aos seus similares disponíveis no mercado. São produtos que apresentam uma qualidade única em função de recursos naturais como solo, vegetação, clima e saber fazer (know-how ou savoir-faire)." 